\title{
Pancreatico-Duodenal Vein
}

National Cancer Institute

\section{Source}

National Cancer Institute. Pancreatico-Duodenal Vein. NCI Thesaurus. Code C53060.

A vein running parallel to the superior and inferior pancreatico-duodenal arteries that drains blood from the pancreas and duodenum into the superior mesenteric or portal veins. 